\title{
A Model of Policy Implementation of Integrated Self-Sufficient City on Transmigration Area (A Case Study in Northern Bengkulu, Bengkulu Province)
}

\author{
Iqbal M. Mujtahid \\ Public Administration Doctoral Program \\ Faculty of Social and Political Science \\ Diponegoro Univeristy, Semarang, Indonesia
}

Prof. Dr. Sri Suwitri

Public Administration Doctoral Program

Faculty of Social and Political Science

Diponegoro Univeristy, Semarang, Indonesia

Prof. Dr. Bambang Supriyono

Public Administration Doctoral Program

Faculty of Social and Political Science

Diponegoro Univeristy, Semarang, Indonesia

Dr. Sofjan Aripin, M.Si.

Faculty of Social and Political Science

Terbuka University

Tarakan, Kalimantan, Indonesia

Received: February 20, 2017 Accepted: June 26, 2017 Published: June 28, 2017

doi: 10.5296/jsss.v5i1.11459 URL: http://doi.org/10.5296/jsss.v5i1.11459 


\begin{abstract}
Development policy in Indonesia is already in the Netherlands starting in colonial times. One of the specified is a transmigration program. This program aims to address the population existence of inequality distribution especially in Java with outside Java, the program evolved into one of the national integration program. As for the approach used in this study is a descriptive approach. The reason for using a descriptive qualitative research methods are intended to describe the phenomenon implementation of development policies and development, self-sufficient city known as (KTM) Lagita in North Bengkulu Regency. In this study data collected consisted of primary data and secondary data. Primary data in data form obtained or collected through interview about KTM Lagita. The primary research studies is very related to the concept of public administration science, policy development and TM development originated and created by Government (management) as a function of dynamic country (Organization), which aims to create the effectiveness and efficiency of the tasks implementation of Government and State. KTM policies in North Bengkulu Regency can be concluded that this policy implementation activity for KTM begins with policy instruments. Policy instrument for KTM is done through the implementation of policy instruments program activities, and it does KTM Pokja (Working Group) formation meeting of the regional coordination.
\end{abstract}

Keywords: KTM, North Bengkulu, Regional coordination, Implementation of development policy and model of self-sufficient city

\title{
1. Introduction
}

Policy development through the policy of transmigration aims in line with the Constitutional Laws Number 29 in 2009 about the changes to this Constitutional Laws No. 15 in 1997 of Transmigration and Government Regulation No. 3 in 2014 about conducting of transmigration aims to improve the welfare of the Homesteader and the surrounding community, improved and equitable regional development, and consolidated these unity and nation.

Transmigration in Indonesia has gone through stages that long with a wide range of product success or failure. In future transmigration program continued, because the territory of the unitary State of Republic Indonesia is geographically has thousands of Islands, with a population separating has not been balanced with the power support nature and the environment.

Issues and policy of resettlement in the context of the history of colonial rule was part of the Netherlands 'Ethical Politics'. This reiterates by Tirtosudarmo (1999) in his work "The Indonesian State's Response to Migration”. The results of his studies explained that transmigration from Java to the outer Java evolve into a welfare Tool to solve this overpopulation problem, poverty, and the density of land in Java. In addition, there is a negative impact on the economy, namely the indigenous population. The migration of Indonesian workers rates internationally also made the point that the exodus will continue in the country.

According to O'Connor in his study (2004), "Effects of Central Decisions on Local Livelihoods in Indonesia: Potential Synergies between the Programs of Transmigration and 
Forest Industrial Conversion". The potential of the transmigration programs that synergize with the forest industry with a proper resettlement is one of management pattern for implementing program.

The transmigration program also contributed in the construction of which with the formation of the new autonomous region (DOB), good village, sub-district, Regency even provinces. This context relates to development region and the progress of the region. Based on the information of data research and Transmigration Information Center of the Ministry of Manpower and Transmigration of Indonesian Republic recorded the year 2012 there are 103 settlements of transmigration in Indonesia which developed into district/city and 382 settlements transmigration became the capital of Sub-District.

The Ministry of regional development, the Village left behind and Resettlement (DPDTT) including the most agencies responsible for tackling these two problems. One of policies effort by the Ministry of DPDTT as a solution is to encourage increased investment around transmigration area, through government programs in the form of Self-contained Self-Sufficient City program (KTM). It has a function as a centre of agricultural activities in the form of agricultural goods processing so and semi-finished as well as agribusiness, agro-industries and special service center plant breeding, education and training activities in the sectors of agriculture, industry, services, and Trade Center area characterized by the presence of the wholesale markets and commodity warehousing.

Self-Sufficient City (KTM) Lagita defined by a decision of the Minister of manpower and transmigration Number KEP. 137/MEN/VI/2008 Regarding the determination of the location of the construction and development of the integrated, self-sufficient city (KTM) in the area of Resettlement in 2009. Independent of Lagita City development area covers a total of 27 settlement of transmigration has been submitted, 1 Unit of Transmigration Settlement is being built, and 59 villages around, with the total area of the region of 99,251 hectares and a population of as many as 158,111 people. The construction of the city will be realized in 5 years. As for the budget needs to exceed 60 billion dollars, which is sourced from the STATE BUDGET, BUDGETS of North Bengkulu Regency, Bengkulu Province, NATIONAL and cross-sector. (Department of Manpower and Transmigration of Bengkulu, 2014)

The model study of policy implementation development of Self-Sufficient City known as (KTM) around transmigration area in North Bengkulu District aiming to circumvent study aspect area, The study of the implementation model of development policy Self-Sufficient City (KTM) in the area of resettlement in North Bengkulu Regency in this study to avoid the vastness of this aspect of the study, then the study is restricted to the theory of Howleet and Ramesh (1995), the contents of the policy and the policy context Grindle (1987), the attitude and ability of the apparatus that Van Metter and Van Horn (1985), communication and bureaucratic structure of George Edward III (1980). All models of these existing theories had influence on the success of the application of the model of out-put public policy.

In addition to these existing theories, this study is also limited to the rules and regulations relating to development policy in North Bengkulu KTM refer to a decision of the Minister of manpower and transmigration Number KEP.137/MEN/VI/2008 Regarding the determination of the location of the construction and development of the integrated, Self-Sufficient City (KTM) in the area of Resettlement in 2009. Transmigration Minister Decree Number 
214/MEN/V/2007 General Guidelines about the construction and development of the integrated, Self-Sufficient City in the area of Resettlement, as well as the legislation of the Republic of Indonesia Number 29 in 2009 about the changes to Constitutional Laws Number 15 in 1997 Of Transmigration and Local Regulations known as (PERDA) number 6 in 2011 about the Medium Term Regional Development Plan known as (RPJMND) of North Bengkulu Regency 2011-2016.

The first stage takes a policy formulation way bases on Dunn (2000: 24), it is a policy system where there is including relationship of reciprocal among three elements, such as public policy, policy implementers and policy circle. The second stages, according to Lane, implementation as a concept can be divided into two parts. First, is implementation (Intention outputs, Outcomes). According to those definitions, the implementation functions consist of intents and purposes, the result as a product and a result of result. Second, the implementation is a function of the equation implementation equal with F (Policy, Formator, Implementer, Initiator, Time). The main emphasis of both these functions is to the policy itself, then the results achieved and implemented by the implementer of a certain period (Sabatier, 1986:21-48).

In the context of Self-Sufficient City (KTM) deliberative policy model is a model that incorporates diversity and interdependence is high against the background of a long conflict of public resources access mastery between the Government and the community as stakeholders. In practice, this model of public policy requires dialogue stakeholders almost in all stages, so it will be able to give birth to a bureaucratic innovation organization of the State/Government in accordance with the characteristics of communities, environmental conditions and the purpose of the participants.

\section{Previous Research}

\section{A. O'Connor (2004)}

The study entitled "Effects of the Central Decisions on Local Livelihoods in Indonesia: Potential Synergies between the Programs of Transmigration and Forest Industrial Conversion". Discuss about the potential of the transmigration program that synergize with the forest industry. In addition to the negative effects on the environment consist of degradation and ethnic conflicts. Indonesia Government programs regarding forest management had uprooted indigenous rights through land grabs. Although the purpose of the Government for effective resource management is however indirectly reduces the availability of land. To that end, the necessary data is empirical and forest conversion design management strategy proper resettlement to compress both local and Central Government program.

\section{B. Shaw (2004)}

Research by Shaw (2004) entitled "Urban Policy in Post-Independent India" is discussing about the urban policies in India post independence. This goes back about urban policy shows tendency in official planning for the management of urban places in this country of India. The first such overall economic policy making by the country that is underestimate the markets role, incentives, private initiative and rely on themselves for investment and management. The second is in terms of policy instruments have been using control directly rather than fiscal incentives and disincentives to influence the outcome. With this deficiency, the Central 
Government should provide a complete urban facilities and best in order to attract industries and new business in particular industries. Although this will requires large investments in urban infrastructure and in particular the largest metro cities with developed markets and basic infrastructure.

\section{Shen (2000)}

Research with the title of "Chinese Urbanization and Urban Policy" describes about urbanization in the developed countries, especially in China. Since the late 1970s in urban China has increased dramatically. This urbanization process will continue until the 21 st century. According to statistics, the urban population is increased by $120 \%$ from $172,450,000$ in 1978 and 379,420,000 in 1998. China is experiencing a rapid expansion of urban areas through the formal process of urbanization. There are two important challenges facing urbanization of China in the 21 st century. The first is improving the urban infrastructure needs through the development of economic management and planning of the town proper and the second is the increasing urban population through natural and rural population to migration to urban areas. Since 1999 there is only 30\% of China's population living in urban areas and the percentage likelihood of increases to $50-70 \%$ in 2150 . Therefore, China implemented a policy for controlling urban migration by adopting the approach indirectly through the regulation of the labor market and also treat the immigrants with the locals with the same treatment. If not, then the quality of a group of wealthy people is achieved at the expense of the poor.

\section{Singh (2004)}

Articles compiled by Singh (2004) entitled "Retail Trade and Urban Policy" is discussing about street vendors in India as economic activity. Therefore, it is need of a short term policy differences and long-term policy. Short-term policies can be seen that street vendors have great numbers and their livelihood depends on this work. While the long-term policy can be seen that sellers need to be reduced in number and are given a special place. The problem is located on the policy regarding spatial in town are limited to street vendors. After analyzed then India's society is divided into four parts. The first was a middle-class community who are interested in commodities prices lower. The second was the poor are illiterates, and migrating from the countryside to seek a living in urban areas. The third is the community that affecting on policy through a variety of ways. Fourth is the Central Government, politicians, institutions, urban development and relating to spatial policy interests.

\section{E. Ying Li (2010)}

The study titled "China's Policy on Rural-urban Migrants and Urban Social Harmony". The result is a rural migrant have suffered serious social exclusion in urban communities in China. However, since the early 2000s, the Chinese Government emphasized social harmony as an important goal of national development. Along with re-orientation of development goals, the life of rural migrants have received the attention of the country is unprecedented. This paper examines the policy changes and check if they have improved the urban social harmony, in particular, in improving the welfare of rural migrants. It was found that policy changes were only partially restored the rights of rural migrants social and political. Some rural migrants are forced to perform extreme acts, such as suicide, crime, and strike to express their 
grievances, so goes against the efforts of the Government to ensure social harmony. Further efforts are needed to improve social inclusion of rural migrants in China's urban areas.

\section{Research Method}

This type of research is qualitative research. According to Creswell (2003), the qualitative approach is an approach to building a knowledge statement based on constructive-perspective (for example, the meanings of which are sourced from individual experience, social values and history, with the aim to build a theory or specific knowledge patterns), or based on the perspective of participatory (for example: orientation toward politics, issues, collaboration, or change), or both. Further, Creswell explained that in qualitative research, knowledge is constructed through interpretation against the various perspectives of the multifunction input all participants involved in the study, researchers not only from the sheer. The source data are diverse, such as observation records, records of interviews, individual experience, and history.

In this study data collected consisted of primary data and secondary data. Primary data in the form of data obtained or collected through interview about Self-Sufficient City knows as KTM Lagita. Interview technique is a technique that can explain the implementation of development policy KTM. To avoid skewed data retrieval results of interviews, then before the researcher will do the justification and classification (Cresswell, 1994) to the subjects which will be its informant. Meanwhile the secondary data in the form of relate documents development program and the development of the KTM Lagita in the Department of Manpower and Transmigration of North Bengkulu Regency supporting or associated with research results. This data is the key to the regulation of the Minister of Manpower and Transmigration of Indonesian Republic Number 214 in 2007 On Guidelines development and Integrated City Development (KTM) in the transmigration area.

Social research uses qualitative descriptive format aims to illustrate, summarize the various conditions, a variety of situations, or various phenomena social reality that there is a community who became the object of research, and attempts to pull that reality to the forefront as a feature, character, nature, models, signs, or a description of the condition, situation, or a particular phenomenon. From the qualitative research in the above sense are not necessarily in the qualitative research should not use data that is a number. Certain things in the data that a number is could be used in data collection. The reason for using a descriptive qualitative research methods are intended to describe the phenomenon of implementation of development policies and the development of Integrated, self-sufficient city (KTM) Lagita in North Bengkulu Regency.

Determination of the number of informants based on certain considerations, taken from people who are directly involved in the KTM program, because they better understand and feel the implementation of the program. Because the determination of the informant conducted in purposive, then informants were selected in this study was the apparatus or officials have the authority and competence of local Government on the policy of the North Bengkulu Regency in the implementation of development policies among other KTM; Secretary, Officials of the Agency's Regional Planning known as (Bappeda), Department of Manpower and Transmigration, Department of Agriculture and Animal Husbandry, Forestry and Plantations, Public Works, the Department of Education and Culture, Department of 
Transportation and The Marine Department, Department of Communication and Information. Office of Youth, Sports and Tourism, The Village Head Chakra, Director of Promotion and Partnership of the Ministry of Regional Development, The Village Left Behind and Transmigration, Subsection Chief of Large City and Directorate of Urban and Rural Resettlement Ministry National Planning Program known as PPN/Bappenas.

\section{Result and Discussion}

The results of this analysis refer to the outline of the problems already on the findings and results of deduce already done analysis. The discussion on Chapter Five consists of: 1) policy development of Self-Sufficient City (KTM) as an acceleration model of development in the transmigration area of North Bengkulu Regency, 2) the effectiveness of policy development on implementation of Self-Sufficient City (KTM), 3) aspects of supporters and a barrier to the implementation of the policy of KTM, 4) existing Models and recommendations implementation model of policy development of Self-Sufficient City (KTM) in North Bengkulu Regency.

\section{A. The policy development of Self-Sufficient City (KTM) in the Resettlement area of North Bengkulu Regency}

The results of the study already analyzed and described obtained from interviews with informants about the policy development of KTM program instrument in the transmigration area of North Bengkulu Province can be formulated as follows:

1). The formulation of program planning through the KTM by involving all the components and any directly related to SEGWAY has programs that can be developed on KTM program area.

2). The program activities of the KTM expected to provide benefits to the community.

3). Program the KTM area must comply with existing planning.

4). Construction of the KTM has already gained positive impact for society, especially after the building of roads and bridges for access to the economy of the community.

Based on the findings of this study which has been formulated in an Policy Instruments development of Self-Sufficient City (KTM) in the transmigration area is seen from the aspect program of activities, the establishment of coordination meetings and Working Group establishment of KTM can be concluded that:

The construction of the KTM has already gained positive impact for the community, especially after the building of roads and bridges for access to the economy of the community. However, its implementation is not as easy as planned until recently its activities between there and no, due to lack of understanding of the program and KTM still ego-cutting on each county in the Working Group Provincial, thus meeting the coordination between SEGWAY and local governments very minimal impact on development policy implementation of KTM stagnated.

The results conclusions of development policy of Self-Sufficient City (KTM) in the transmigration area are there in North Bengkulu Regency is not going according to the expected development program planning both instruments as seen from the aspect of the program, the establishment of coordination meetings and Working Group known as Pokja. The results of these findings prove that the program development policy of Self-Sufficient 


\section{MInstitute Macrothin}

Journal of Social Science Studies

ISSN 2329-9150

2018, Vol. 5, No. 1

City (KTM) in North Bengkulu needed redesign and revitalization of the existing Self-Sufficient City (KTM) development policy with a model fitting in accordance with the KTM concept of a development planning policy.

For the realization of the KTM program development activities, then local government of North Bengkulu Regency need solid teamwork with a harmonious working group (Pokja)/institutional organizations structure can also determine the success of the planning and program development policy of transmigration in the KTM North Bengkulu. Pokja $\mathrm{KTM}$ /organizational structure is part of the institutional diversity indicate types and dynamics are different from one another because of institutional factors influence internally and externally. At this level, the institutional dynamics is understood as a "pattern of institutional relationships within and between institutions". Therefore, the institutional dynamics of conceptually required a comprehensive and holistic concept to understand the specificity of the dynamics and institutional typology in supporting the attainment of KTM program development policy in North Bengkulu.

\section{B. The Effectiveness Implementation of Policy Development Self-Sufficient City (KTM) Recently}

Based on the results of the already formulated on the effectiveness implementation of policy development program Self-Sufficient City (KTM) Lagita on aspects of Standard Operation Procedure, Human Resources utilization, planning programs/activities, financing, infrastructure development, and cooperation can be concluded that:

Management of the KTM Lagita this is the first time a standard Operational Procedure (SOP) has not been adequate, the second planning programs/activities have not been effective. Third, the financing was minimal and limited to the budget. And the fourth is cooperation for a while, specialized agencies in particular, it is not yet established close cooperation with the other regions because that is the focus of us to build tourism yet no realization of the associated region Center KTM.

The human resources utilizations have the readiness in technical aspects of the construction of a KTM. Human Resources readiness owned currently needed new innovation and change. In addition, there is still a lack of the number of staff in dealing with development programs need to be improved as well as the existence of a KTM community support against the current KTM development policies need to be in the preserve and in the increase.

Infrastructure development still have constraints and maximum yet, well that the construction of the school, a place of health, agriculture and transportation is still low due to still many roads in damaged condition to support the production of the community. The repair of irrigation and drainage network of the budget for the repair of irrigation canals already do, especially the construction of the first large town centre and the second building of the lowliest KTM large enough and heavy enough even though it has not been too good and the maximum.

The effectiveness implementation of development policy Lagita KTM bases on Standard Operation Procedure aspect, Human Resource utilization, planning programs/activities, financing, infrastructure development, and cooperation can certainly be a consideration for the regional Government of North Bengkulu Regency to enforce the concept of development 
policy of transmigration areas on KTM Lagita. Policy development in the area of resettlement KTM Lagita as one of the development program is primarily directed towards agricultural development, namely the increase in agricultural productivity. Increase in agricultural productivity can expect support increased income, prosperity and equitable development results. According to Utomo (2005) to realize the resettlement areas in this case in Lagita region, then need to be developed for rural agro-industries centers that can absorb the manpower in the countryside and spur the growth of the region.

Policy development in the resettlement area KTM Lagita as one of the development programs need to built infrastructure and market access, so going on harmonization of regional development. But the fact of the matter through the Department of manpower and transmigration of North Bengkulu Regency stating KTM North Bengkulu resettlement has not run effectively. If referring to the opinions expressed by Sumardjo (2004:26) stated that the transmigration areas is the region where the product is available and the Homesteader of the surrounding community has a comparative advantage. The area could potentially be large city area development, namely the development of the agricultural sector and rural agriculture-based. Therefore, transmigration area of Lagita North Bengkulu when running effectively and efficiently, then potentially be territory development area, namely the integration of large city farms and villages production center that grew and flourished due to the operation of the system and the efforts of agro-industrial agribusiness.

Infrastructure optimization development in the transmigration area of development, particularly in the area of Lagita North Bengkulu as manifestations of the development resettlement region as an effort to increase develop areas that have the potential of natural resources with specific commodities that are managed with integrated fill the shortage of human resources through the transmigration program (Priyono \& Fatimah, 2007).

The basic purpose of development areas and spatial arrangement of resettlement is to establish a system for the settlement of functionally is a container that can be concocted a variety of input (input) and appropriate technologies so as to enable the realization of the life of transmigration. The expected settlement system since the beginning has the ability to meet the needs of its own and is capable of growing to reach the level of prosperity at least above the sub system.

Appropriate spatial concept, the transmigration settlement shall become an integral part of the development efforts of the region (Muchdie, 2006). Further, it says, in relation to the development of the region, efforts to accelerate the development of resettlement areas can be done through the development of agriculture which is followed by the development of processing industry of agricultural results.

\section{The Supporting Aspects and Obstacles to the Implementation development policy of Self-Sufficient City (KTM)}

There are existence of potential natural resources (land, water, etc.), resources of artificial (roads, educational facilities, health care, irrigation, etc.) and human resources that are large enough to be developed either in quantity or quality through management of the proper, effective and efficient.

According to the Ministry of Manpower and Transmigration (2006) development of KTM is 
one of the metropolitan area development concept which was developed by the Ministry of manpower and transmigration Resettlement in the region. According to Rustiadi et al. (2005) the development of the region emphasize the relationship between metropolitan rural area with urban hierarchical, so that it formed a hierarchy of regions. In this case between the main developments region with it's around region. Development of small cities and facilities basic services and markets for agricultural products in the rural area will improve the well-being of rural communities. Development of small towns, in the context of metropolitan can positively promote the development of its hinterland regions, particularly for rural agricultural patterns of transforming sub system into commercial and industrial agriculture patterns as well as integrate the urban and rural economies.

Based on results from the effectiveness of the implementation of the policy content (content of policy) the development resettlement in the lowliest KTM North Bengkulu Regency in the perspective of the type of benefits, the degree of changes to expect and resources involved can be summed up as follows:

The benefits of development policies in the area of resettlement KTM North Bengkulu has yet to be felt by the community and benefit the region, be it economic benefits, education, income generation, as well as access. The expected Changes in the degree of development policy in the area of resettlement KTM North Bengkulu Regency is expected both in the development as well as economic, but the fact that there are still not giving the influence of changes that occur on the improvement of the economy. The resources involved are still minimal, because each agency has yet to supervise the KTM specifically. Still the lack of technical personnel to handle the special Ministerial Conference as well as extension officers, technical field (cultivation, capture, processing), other stakeholders were also involved but also still limited. In addition, policy development in the area KTM constrained due to less his solid performances from almost all Central Government ministries from 14 sectors in need their earnestness against the KTM.

The effectiveness of the implementation of the policy content (content of policy) from the town of Self-Sufficient City (KTM) or often called Self-Sufficient City certainly is also inseparable from the support of the policy of settlements. Settlement policies by local governments can determine access to land is distributed through the settlement which is also adapted to the category of cultural differences as a locus of ethnic identity and political action that can provide the benefits and changes in society (Hoshour, 2000). Integrated, self-sufficient city is part of the urban development planning policy, in substantial which can be adopted by local governments of North Bengkulu Regency as Brazil's national program policies that support positive social change in the year 2010.

\section{The Model Existing of Implementation development policy KTM in North Bengkulu Regency}

Implementation development policy of Self-Sufficient city advantaging surely had the objective of which is to accelerate the construction and development of resettlement areas, as well as happened in North Bengkulu Regency. To achieve the intended objectives must surely require different efforts and work program and in their implementation is certainly still there are problems and obstacles caused by some aspects as described above. Thus it need for process approach constructively. 


\section{Macrothink}

According to the results of the study are then to be more easily understood in the development policy implementation model KTM can be visualized as follows:

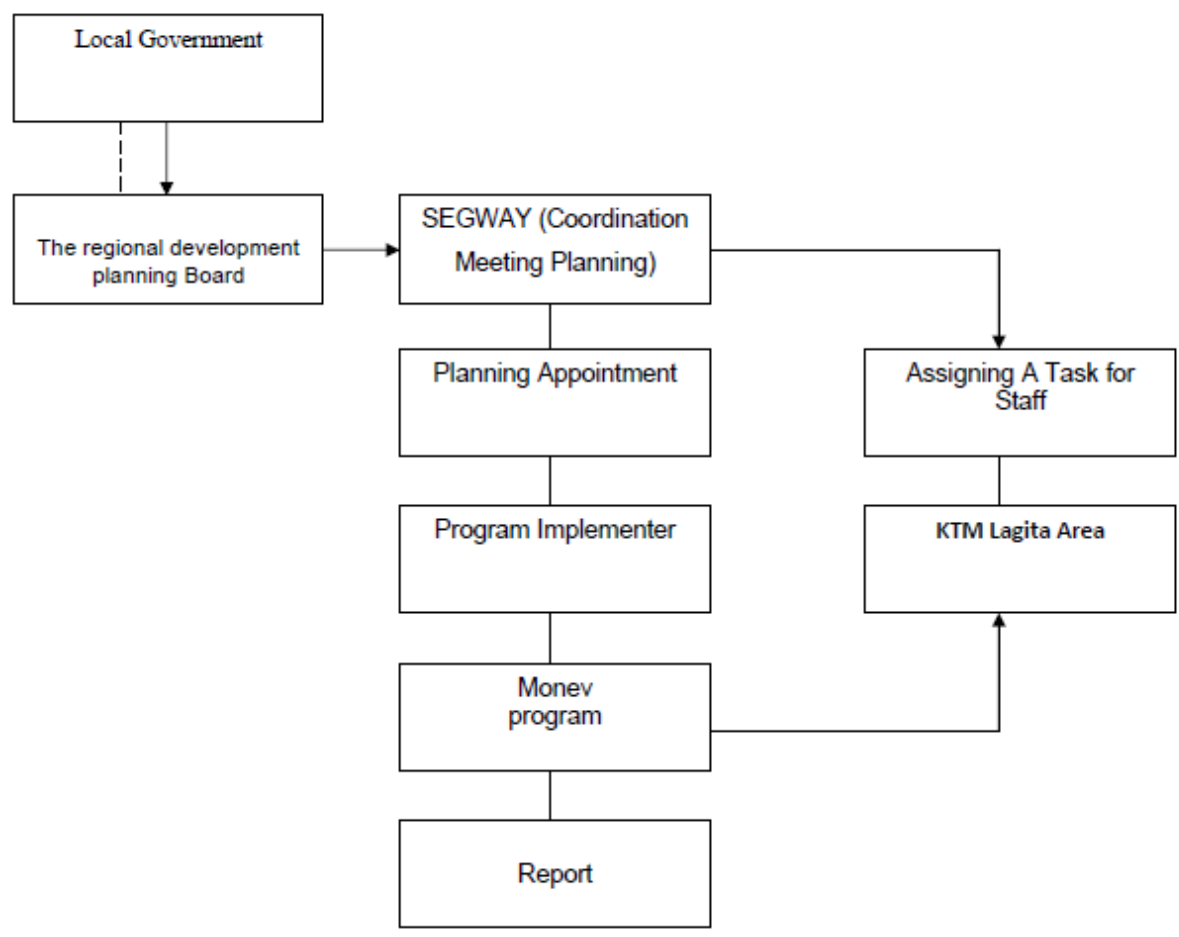

Figure 1. The Existence Model of Standard Operational Procedure (SOP)

Source: The Research Result, 2015.

The model existing of policy implementation KTM recently in the transmigration area in North Bengkulu, Bengkulu Province in this study can be seen base on several aspects as follows:

1). Policy Instruments KTM Lagita (Howleet \& Ramesh, 1995) comprising: formulation of instrument program activity establishment of KTM, creating Working Group and meeting coordination.

2). The effectiveness of development policy KTM Lagita Gridle (1980). Edward III (1984), Mazmanian and Sabatier (1986), as well as Mazmanian and Sabatier (1986) composed of: SOP, Human Resource Utilization, planning programs/activities, financing, infrastructure development, and cooperation.

$3)$. The supporting and obstacle aspects to the implementation of the policy of George C. Edward III (1980), Grindle (1980), Edward III (1984) consists of: Policy Content (Content of Policy), the policy Context (Context of Policy), the attitude and ability of Executor, communications and bureaucratic structure.

Existing models in the implementation of the policy of the current KTM on resettlement area in North Bengkulu, Bengkulu Province of in this study more agree on a position supporting the theory of Grindle (1980), Mazmanian and Sabatier (1986). According to the empirical basis (Grindle, 1980) in the implementation of policies is part of the compliance perspective of external factors that also affect the Organization's performance. In factual perspective 
according to Grindle (1980) the existing development policy model KTM in North Bengkulu can also focus its attention on non-organizational factors because it is according to the Grindle can also affect the implementation of the policy will be carried out by the regional Government of North Bengkulu Regency.

Implementation model of public policy expressed Grindle (1980) said that the success of the process of implementation of the policy is also very dependent on the activities of the program that has been designed and enough financing, in addition to being influenced by the Content of Policy (policy content) and Context of Implementation (implementation context). The success of the existing policy implementation models can also be adapted to the Content of Policy (content policy), includes the following things;

1). The interests that are affected by the policy.

2). The types of benefits to be generated.

3). The degree of change that is desired.

4). The position of policy makers.

5). Implementing the program.

6). The resources mobilized.

\section{Conclusion and Suggestion}

Bases on results of research on these aspects, related to KTM policy in North Bengkulu Regency can be concluded that this policy implementation activity for KTM begins with policy instruments. Policy instruments for KTM are done through the implementation of policy instruments program activities, and it does KTM Working Group formation meeting of the regional coordination. The formulation of the program carried out in the forum meeting later through SEGWAY poured in North Bengkulu Regency RPJMD. As for this KTM Working Group itself also consists of a central, province and Regency, each of which is chaired by the Governor and Regent for the County.

The policy Implementation of the KTM North Bengkulu Regency had the support of the phenomenon of content policies or content of policy. Aspects of that support is the aspect of the type of benefits, this is because the public would certainly benefit by having the area KTM Lagita. KTM policies this will encourage the public to do empowerment and mobilization of the community will turn smoothly. Besides aspects of agriculture, education, health and others will hopefully feel its benefits either directly or not that touched on the interests of the community. In addition to the phenomenon of the degree of change that is expected to also supporting aspects of the implementation of the KTM policy of North Bengkulu. This is due to the magnitude of the expectations of changes that will happen with the KTM in the transmigration area of North Bengkulu.

The support of stakeholders and the ability of the apparatus also became a supporter of the implementation of the policy aspects of the KTM in North Bengkulu. This is demonstrated by all elements of society, the local government apparatus, providing support for the implementation of development activities and the development of KTM in North Bengkulu. All the capabilities of the apparatus have also been deployed and maximized possible optimalization. As for the phenomenon of communication becomes a supporting aspect i.e. the existence of a consistency of Government, in this case the Government continue to make 


\section{Ml Macrothink}

a commitment in delivering related KTM communications programs continuously. The Government has shown consistency with the coordination of activities and meetings of the forum to the associated element. Although in his journeys there are still various obstacles.

Inadequate coordination resulting in no occurrence of uniformity, synchronization in the implementation of the KTM policy, so the result is less able to run as expected. The ego is still the sector and related service found tent to be more focused on the field of duty, rather than serious synergize for the success of the program. In addition, in the implementation of activities yet the existence of a clear Standard Operating Procedure and less collaboration between SEGWAY related services tends to lead to more focus on field duty respectively.

Lack of resources involved, staff or employees are very few who actually controlled the field assigned MINISTERIAL CONFERENCE every SEGWAY. Then funding resources is very minimal became a major obstacle in the development of the KTM Lagita in North Sumatra. This is shown from the still dependent regional government with the help of the Centre only. Aspects of the context of the policy on the phenomenon of the support infrastructure are still a bottleneck in KTM Lagita. The infrastructure is still inadequate from all aspects, either from the means of agriculture, education and others. Agricultural infrastructure is very minimal and all infrastructures have not occur a significant development.

For communication over this aspect of media used by the local government is still a manual so as long as this is still a factor restricting the implementation of KTM policies in North Bengkulu. Aspects of the structure of the bureaucracy that is the fragmentation of work unit not supported coordination work unit on local government plus the implementing difficult routines changed. Besides that became obstacles also is a frequent occurrence of mutations of the competent authority or Agency as well as the related officials turn over this region often used as KTM political commodity for the perpetrators of political election. That is not less important is the legal umbrella in case it hasn't been made yet and applied regulations areas that directly relate to implementation of the KTM Lagita in North Bengkulu.

The success of the implementation of the KTM policy can be felt by the community as appropriate and certainly need initially performed a variety of strengthening and improvement of the policy implementation. In order for such strengthening can be realized if the strengthening of the institutional functions in every sector can formulate policy are clear and measurable. For that researcher has a number of recommendations that can be used as a reference regarding the following matters:

A). Synergizing the different types of policy instruments for the implementation of the KTM policy with attention to local conditions and regulations as well as regional development.

B). The effectiveness of policy implementation is the KTM can be seen through the development of means of supporting compliance with the prevailing regulation and theoretical concepts about the implementation of the policy.

C). Disseminating the policy to the entire KTM SEGWAY that the construction of the crosscutting nature of the KTM program so that it requires the coordination of cross-cutting, either at central level or at regional level, as well as between the Central Government and regions to be able to increase and equitable well-being, as well as meet the basic services.

D). In implementing comprehensive policies in KTM needed an ideal model and theoretical 
concepts regarding the implementation of the policy, the need to portray the role of the actors, good actors in Government, as well as interest groups, academics and the media.

This study surely contains a weakness because it was just a case study on a KTM in the local governments, while in Indonesia there are currently $48 \mathrm{KTM}$ that spread in various areas. The local Government of North Sumatra became the focus of the study because the researchers had the view that KTM there still is unique and the need for feedback and improvement in the implementation of the KTM policy. There are various interesting phenomena to do further research, but because of the limitations with regard to both researchers possessed the ability of analysis, time and effort then researchers conduct analysis on the phenomenon of which include; determination of policy instruments policy implementation, KTM, the contents of the policy, the policy context, the attitude and ability of executor, communications and bureaucratic structure.

\section{References}

Cresswell, T. (1996). In placelout of place: geography, ideology, and transgression. Minneapolis: University of Minnesota Press.

Creswell, J. W. (2003). Research Design: Qualitatif, and Mixed Approach (2nd ed). Thousand Oaks, California: Sage Publications.

Dunn, W. N. (2003). Analisis Kebijakan Publik. Yogyakarta: Gadjah Mada University Press.

Edwards, III., \& George, C. (1980). Implementing Public Policy, Congressional Quarterly Inc., United States of America.

Grindle, M. S. (ed). (1980). Politics and Apolicy Implementation in the Third World. New Jersey: Princetown University Press.

Grindle, Me. S., (Ed). (1980). Politics and Apolicy Implementation in the Third World. New Jersey: Princetown University Press.

Hoshour, C. A. (2000). Relocating development in Indonesia: A look at the logic and contradictions of state-directed resettlement (Order No. 9988619). (304590414). Retrieved from http://search.proquest.com/docview/304590414?accountid=25704

Howleet, M., \& Ramesh, M. (1995). Studying Public Policy: Policy Cycles and Policy Subsystems. Oxford University Press. USA.

Howleet, M., \& Ramesh, M. (1995). Studying Public Policy: Policy Cycles and Policy Subsystems. Oxford University Press. USA.

Keputusan Menteri Tenaga Kerja dan Transmigrasi. (2007). Peraturan Menakertrans Nomor 214 Tahun 2007 Tentang Pedoman Umum Pembangunan dan Pengembangan Kota Terpadu Mandiri di Kawasan Transmigrasi. Jakarta: Sekretariat Kabinet.

Keputusan Menteri Tenaga Kerja dan Transmigrasi. (2008). Keputusan Menakertrans Nomor 137 Tahun 2008 Tentang Penetapan Lokasi Pembangunan dan Pengembangan Kota Terpadu Mandiri (KTM) di Kawasan Transmigrasi. Jakarta: Sekretariat Kabinet.

Mazmanian, D. H., \& Sabatier, P. A. (1986). Implementation and Public Policy: New York, Harper Collins.

Muchdie. (2006). Peranan Industri Pengolahan Hasil Pertanian Dalam Pengembangan Wilayah Transmigrasi. Tesis. Bogor: Fakultas Pasca Sarjana IPB. 
O'Connor. (2004). Effects of Central Decisions on Local Livelihoods in Indonesia: Potential Synergies between the Programs of Transmigration and Industrial Forest Conversion. Population and Eivironment, 319-333. https://doi.org/10.1023/B:POEN.0000036483.48822.2f

Pemerintah Provinsi Bengkulu Dinas Tenaga Kerja dan Transmigrasi. (2009). Rencana Detail Tata Ruang Pusat Kota Terpadu Mandiri (KTM) di Kawasan Lagita Kabupaten Bengkulu Utara Provinsi Bengkulu. Bengkulu.

Peraturan Daerah Bengkulu Utara. (2011). Peraturan Daerah Nomor 6 Tahun 2011 Tentang Rencana Pembnagunan Jangka Menengah Daerah Kabupaten Bengkulu Utara 2011-2016. Bengkulu Utara: Sekretariat Daerah.

Priyono, \& Fatimah, S. (2007). Konsep Kawasan Transmigrasi Lokasi Pemukiman Transmigrasi (LPT) dan Wilayah Pengembangan Transmigrasi (WPT) sebagai alat Pembangunan Daerah. Jakarta: Depnakertrans.

Pusat Data dan Informasi Ketransmigrasian Badan Penelitian Pengembangan dan Informasi Kemenakertrans R.I. (2012). Data Strategis Ketransmigrasian. Jakarta: Kemenakertrans.

Rustiadi, E., \& Hadi, S. (2006). Pengembangan Agropolitan sebagai Strategi Pembangunan Perdesaan dan Pembangunan Berimbang. Di dalam: Kawasan Agropolitan Konsep Pembangunan Kota-kota Berimbang. Bogor: P4W-LPPM IPB.

Shaw, A. (2004). Urban Policy in Post-Independent India. Economic and Political Weekly, 31(4), 224-228.

Shen, J. (2000). Chinese Urbanization and Urban Policy. China Review, 455-480.

Singh, G. (2004). Retail Trade and Urban Policy. Economic and Political Weekly, 39(23), 2410-2412.

Sumardjo. (2004). Kemitraan Agribisnis. Jakarta: Penebar swadaya.

Tirtosudarmo, R. (1999). The Indonesian State's Response to Migration. Journal of Social Issues in Southeast Asia, 14(1), 212-228. https://doi.org/10.1355/SJ14-1I

Utomo, M. (2005). Tinjauan Kritis Kebijakan dan Implementasi Penyelenggaraan Transmigrasi. Makalah disampaikan pada Semiloka Transmigrasi dan Penguatan NKRI. (30 November 2005). Jakarta.

Van Meter, Donal, S., \& Carl, E., Van Horn, (1975). The Policy Implementation Process: A Conceptual Framework. Administration \& Society, 6(4), 445-487. https://doi.org/10.1177/009539977500600404

Ying, L. (2011). China's Policy on Rural-urban Migrants and Urban Social Harmony. Asian Social Science, 7(7).

\section{Copyright Disclaimer}

Copyright for this article is retained by the author(s), with first publication rights granted to the journal.

This is an open-access article distributed under the terms and conditions of the Creative Commons Attribution license (http://creativecommons.org/licenses/by/3.0/). 